\title{
Ketoksikan Akut dari Ekstrak Etanolik Daun Jarak Pagar (Jatropa curcas) pada Mencit Jantan Galur Balb/C
}

\author{
Hanif Nasiatul Baroroh ${ }^{*)}$ dan Eka Prasasti Nur Rachmani
}

Jurusan Farmasi, Fakultas Kedokteran dan Ilmu-ilmu Kesehatan, Universitas Jenderal Soedirman, Purwokerto 53123

Diterima 20-04-2011 Disetujui 25-03-2013

\begin{abstract}
The acute toxicity of Jatropa curcas leaves on Balb/C male mice was studied in rats. This research aimed to determine acute toxicity, evaluate spectrum of toxic effect and mechanism that caused the death of animal test after administration of ethanolic extract of $J$. curcas leaves, single dosage orally on 24 hours observation. The research used male mice, which are divided into 5 groups. Group I was negative control with CMC-Na. Group II, III, IV, and V were given extract with dose of $1400 \mathrm{mg} / \mathrm{kgBW}, 2240 \mathrm{mg} / \mathrm{kgBW}, 3584 \mathrm{mg} / \mathrm{kgBW}$ and $5734 \mathrm{mg} / \mathrm{kgBW}$, respectively. Evaluation of the toxic symptoms and death of animal test was done for 24 hours. If the animal test was died before 24 hours then it underwent surgery to take the heart, liver, lung, and kidney. In the end of the evaluation, all mice were killed to take the vital organs for histopathologic examination. No mortality was observed during study. The test resulted $\mathrm{LD}_{50}$ of ethanolic extract from J. curcas leaves using Balb/C male mice was $5734 \mathrm{mg} / \mathrm{kg}$ of BW. It was categorized as practically not toxic. Administration of the extract did not cause alterations of animal behaviours. Histopathology examination shows inflammation in lung, liver, and kidney after administration of the extract.
\end{abstract}

Keywords: acute toxicity, Jatropa curcas, median lethal dose $\left(\mathrm{LD}_{50}\right)$

\begin{abstract}
ABSTRAK
Telah dilakukan studi ketoksikan akut dari daun Jatropa curcas pada tikus. Tujuan penelitian ini adalah mengetahui ketoksikan akut, mengevaluasi spektrum efek toksik dan mekanisme perantara efek toksik setelah pemejanan ekstrak etanol daun J. curcas dosis tunggal dengan pengamatan selama 24 jam. Penelitian ini menggunakan mencit jantan yang dibagi menjadi 5 kelompok. Kelompok I adalah kontrol negatif yang diberikan CMC Na. Kelompok II, III, IV, dan V diberikan ekstrak dengan masing-masing dosis 1400, 2240, 3584, dan $5734 \mathrm{mg} / \mathrm{kgBB}$. Pengamatan gejala toksik dan jumlah hewan uji yang mati dilakukan selama 24 jam. Apabila ada hewan uji yang mati sebelum 24 jam setelah pemberian sediaan uji, mencit dibedah untuk diambil jantung, hati, paru-paru, dan ginjal. Pada akhir masa uji yaitu jam ke-24 sisa mencit yang masih hidup dikorbankan untuk selanjutnya diambil organ-organ vitalnya untuk pengamatan histopatologi, yang bertujuan untuk mengevaluasi mekanisme terjadinya efek toksik atau kematian. Selama penelitian tidak ditemukan kematian pada hewan uji. Hasil penelitian menunjukkan nilai $\mathrm{LD}_{50}$ dari ekstrak etanol daun $J$. curcas adalah $5734 \mathrm{mg} / \mathrm{kgBB}$ dengan kategori praktis tidak toksik. Pemberian ekstrak tidak menyebabkan perubahan perilaku pada hewan uji. Hasil pemeriksaan histopatologi menunjukkan terjadinya inflamasi pada organ ginjal, hati dan paru.
\end{abstract}

Kata Kunci: Jatropa curcas, median lethal dose $\left(\mathrm{LD}_{50}\right)$, toksisitas akut

\section{PENDAHULUAN}

Penggunaan tanaman sebagai obat tradisional masih banyak dilakukan masyarakat Indonesia selain obat-obatan yang berasal dari bahan kimia. Hal ini didukung oleh adanya sumber bahan obat dari bahan alam nabati yang tumbuh berlimpah di Indonesia dan mempunyai potensi yang cukup besar. Hal ini juga disebabkan karena penggunaan obat sintesis memiliki efek samping yang berbahaya, seperti: keluhan saluran pencernaan, gangguan ginjal, alergi, toksis atau bersifat racun pada hati serta harga yang relatif mahal. Keamanan obat tradisional diyakini lebih tinggi daripada obat sintesis, padahal produk herbal merupakan produk fitokimia yang dapat mendorong, menghambat atau meracuni sistem metabolisme manusia.

\footnotetext{
*Telp: +628157940671

Email: h_baroroh@yahoo.co.id
} 
Penelitian mengenai obat tradisional terus berlangsung bahkan meningkat jumlahnya akhir-akhir ini. Meskipun demikian, dalam kenyataannya hingga saat ini baru beberapa penelitian obat tradisional ataupun tanaman obat yang digunakan dalam fasilitas pelayanan kesehatan. Obat yang digunakan pada fasilitas pelayanan kesehatan harus memenuhi persyaratan aman, bermanfaat dan sudah terstandaridisasi. Bukti yang diperlukan harus didasarkan pada data yang sahih (Depkes RI 2000). Pada kenyataannya masih banyak obat tradisional yang belum diketahui keamanannya. Berdasarkan hal tersebut, perlu dilakukan uji toksikologi terhadap obat tradisional yang dapat bermanfaat sebagai dasar evaluasi keamanan praklinik untuk memperkirakan resiko penggunaannya pada manusia (Honggodipuro 2007).

Pada umumnya, penggunaan obat tradisional untuk pengobatan, dosis atau takaran yang digunakan tidak sesuai standar resmi yang menyatakan adanya dosis lazim dan dosis maksimum. Hal ini memungkinkan terjadinya efek samping akibat penggunaan obat tradisional yang melebihi dosis standar atau dosis lazim (Ma' at 2004).

Salah satu obat tradisional yang dikonsumsi masyarakat Indonesia adalah daun jarak pagar (J. curcas). Tanaman jarak pagar mengandung senyawa saponin, polifenol, dan flavanoid yang berpotensi sebagai antimikroba, antioksidan, antikanker, dan antiinflamasi (Thomas et al. 2008; Rathee et al. 2009). Baroroh \& Warsinah (2009), melaporkan bahwa ekstrak etanol daun jarak pagar dengan dosis $300 \mathrm{mg} / \mathrm{kgBB}$ tikus yang diberikan secara per oral dapat menghambat peradangan sebesar $23,25 \%$ dan dosis $500 \mathrm{mg} / \mathrm{kg}$ berat badan dapat mengurangi rekrutmen neutrofil pada kaki tikus. Menurut Uche dan Aprioku (2008), ekstrak metanol daun jarak pagar 10-80 mg/kgBB memiliki aktivitas analgesik dan menghambat inflamasi pada mencit yang diinduksi albumin telor. Telah dilaporkan bahwa daun jarak pagar memiliki aktivitas antioksidan yang paling tinggi dan memiliki aktivitas antiinflamasi melalui mekanisme penghambatan iNOS (Oskueian et al. 2011). Selain itu ekstrak etanol $J$. curcas pada dosis $200 \mathrm{mg} / \mathrm{kgBB}$ menimbulkan efek teratogen pada mencit (Almahdy 2005). Dalam pengembangan obat herbal terstandar selain aktivitasnya secara farmakologi, perlu diketahui juga potensi keamanannya melalui uji toksisitas sehingga dapat diketahui rentang dosis yang aman pada pemakaian obat tersebut dalam terapi. Namun, kajian ilmiah tentang ketoksikan akut dari daun jarak pagar belum dilaporkan. Berdasarkan hal tersebut perlu dilakukan penelitian tentang uji ketoksikan akut dari daun jarak pagar pada mencit.

\section{BAHAN DAN METODE}

Bahan utama dalam penelitian adalah hewan mencit putih jantan galur Balb/C umur 2-3 bulan, berat 20-30 g, daun jarak pagar (J. curcas), etanol, akuades, formalin, $\mathrm{NaCl} 0,9 \%$, parafin, pewarna hematoksilin-eosin, xylol, dan albumin. Alat yang digunakan adalah tabung maserasi, evaporator, alat gelas (Pyrex), timbangan analitik, spuit injeksi per oral ukuran $1 \mathrm{~mL}$, alat timbangan hewan uji, alat bedah, spatel, holder mencit, gelas objek, dan mikroskop cahaya.

Daun jarak pagar diambil dari Kebun Biologi Unsoed dilanjutkan dengan pengeringan di bawah sinar matahari dengan tutup kain hitam, kemudian dipanaskan pada suhu $70^{\circ} \mathrm{C}$. Pengeringan berlangsung selama 4 hari. Lima ratus gram serbuk kering dimaserasi dalam 2 L etanol dan didiamkan selama 24 jam, selanjutnya dilakukan remaserasi dengan $2 \mathrm{~L}$ etanol, didiamkan 4 hari. Sari etanol dievaporasi, dianginanginkan sampai diperoleh ekstrak kental etanol daun jarak pagar.

Uji toksisitas akut dilakukan terhadap mencit (Akhila et al. 2007; Wahyono et al. 2007). Hewan uji yang digunakan adalah mencit jantan galur Balb/C sebanyak 25 ekor. Dua puluh lima ekor mencit dibagi secara acak dalam 5 kelompok sama banyak. Sebelum mencit mendapat perlakuan dengan sediaan uji, terlebih dahulu mencit diaklimatisasikan dengan lingkungan penelitian. Kemudian mencit dipuasakan 18-24 jam dan tetap diberikan minum sebelum perlakuan dengan sediaan uji. Masing-masing kelompok diberi perlakuan sebagai berikut: kelompok I diberi $1 \mathrm{~mL}$ larutan CMC Na 0,5\% secara oral dosis tunggal (kelompok kontrol negatif ), kelompok II diberi ekstrak etanol J. curcas per oral dosis $1400 \mathrm{mg} / \mathrm{kgBB}$, kelompok III diberi ekstrak etanol $J$. curcas per oral dosis $2240 \mathrm{mg} / \mathrm{kgBB}$, kelompok IV diberi ekstrak etanol J. curcas 1 per oral dosis $3584 \mathrm{mg} / \mathrm{kgBB}$ dan kelompok $\mathrm{V}$ diberi ekstrak etanol $J$. curcas per oral dosis $5734 \mathrm{mg} / \mathrm{kgBB}$.

Pengamatan gejala toksik dilakukan selama 24 jam dan pada 3 jam pertama setelah pemberian sediaan uji, pengamatan dilakukan intensif. Kriteria pengamatan meliputi pengamatan fisik terhadap gejala-gejala toksik: kulit dan bulu, mata dan mukosa membran, sistem pernafasan, sistem peredaran darah, sistem otonom dan saraf pusat, sistem saluran cerna, sistem geniteurinaria, pola perilaku serta aktivitas somatomotor, dan jumlah hewan yang mati. Apabila 
ada hewan uji yang mati sebelum jam ke-24 dan yang masih hidup setelah pemberian sediaan uji, diambil beberapa organ (paru-paru, hati, ginjal, dan jantung) untuk pengamatan histopatologi.

\section{HASIL DAN PEMBAHASAN}

Pemberian dosis tunggal ekstrak etanolik daun jarak pagar dengan dosis bertingkat, dimulai dari dosis terendah yaitu dosis terbesar yang tidak mematikan hewan uji, hingga dosis tertinggi, yaitu dosis terkecil yang menyebabkan kematian seluruh atau hampir seluruh hewan uji (10-90\% kematian hewan uji) (Loomis 1978; Akhila et al. 2007). Pada penelitian ini ada empat kelompok perlakuan yang mendapatkan dosis berturut-turut 1400, 2240, 3584, dan $5734 \mathrm{mg} / \mathrm{kgBB}$. Selain kelompok perlakuan juga ada kelompok kontrol yang hanya diberikan Na-CMC $0,5 \%$. Penentuan dosis pada penelitian ini berdasarkan dosis efektif daun jarak pagar sebagai antiinflamasi yaitu pada $500 \mathrm{mg} / \mathrm{kg}$ (Baroroh \& Warsinah 2009). Dosis $1400 \mathrm{mg} / \mathrm{kgBB}$ merupakan 2,8 kali dari dosis efektif merupakan dosis terbesar yang tidak mematikan hewan uji tapi masih memiliki efektivitas. Dosis II dan selanjutnya merupakan kelipatan dari 1,6 kali dari dosis yang pertama. Data yang diperoleh meliputi tolak ukur kuantitatif berupa potensi ketoksikan akut $\left(\mathrm{LD}_{50}\right)$ dan tolak ukur kualitatif meliputi gejala toksik hasil dari pengamatan terhadap hewan uji dan hasil pengamatan histopatologi organ.

Hingga dosis terbesar $5734 \mathrm{mg} / \mathrm{kgBB}$ pada pemberian dosis tunggal oral ekstrak etanolik daun jarak pagar tidak ditemukan adanya kematian setelah pemberian bahan uji. Pemberian ekstrak etanolik daun jarak pagar pada mencit sampai dosis maksimum secara teknis dapat diberikan tidak menimbulkan kematian hewan uji dari keseluruhan kelompok selama masa uji 24 jam (Tabel 1). Berdasarkan hal tersebut, maka $\mathrm{LD}_{50}$ sediaan uji tidak dapat dihitung atau dinyatakan dengan pasti, namun hanya dapat dinyatakan harga $\mathrm{LD}_{50}$, sebatas peringkat dosis tertinggi yang secara teknis dapat diterima hewan uji, yaitu lebih dari $5734 \mathrm{mg} / \mathrm{kgBB}$ dengan kategori praktis tidak toksik berdasarkan kategori ketoksikan dari Loomis (1978).

Pengamatan gejala toksik yang timbul akibat pemberian sediaan uji dilakukan pada 3 jam pertama setelah pemberian sedíaan uji selama masa uji 24 jam. Sebelum pengamatan dilakukan, harus diketahui kebiasaan dan kondisi awal dari hewan uji. Hal ini dilakukan untuk mengetahui jika ada perubahan dari kebiasaan dan kondisi setelah pemberian sedíaan uji.

Dari hasil pengamatan terhadap gejala-gejala toksik ternyata tidak mempengaruhi kondisi kesehatan dan kebiasaan hewan uji. Hal ini menunjukkan bahwa ekstrak etanolik daun jarak pagar tidak mempengaruhi perilaku, gerakan, perubahan otot, bentuk dan warna kulit, serta defekasi, hanya pada kelompok perlakuan dosis $5734 \mathrm{mg} / \mathrm{kgBB}$ menunjukkan perilaku dan gerakan yang lemah (Tabel 2).

Hasil pemeriksaan histopatologi organ pada hewan uji setelah pemberian per oral ekstrak etanolik daun jarak pagar dosis tunggal menunjukkan adanya perubahan pada tingkat seluler. Pemberian secara oral ekstrak etanolik daun jarak pagar (J. curcas) pada mencit mempengaruhi organ hati (peradangan, degenerasi vakuoler, dan nekrosis), ginjal (peradangan), dan paru (peradangan) (Tabel 3).

Pada pemeriksaan organ hati terjadi peradangan pada semua kelompok perlakuan ekstrak dosis terendah sampai tertinggi, dan pada perlakuan ekstrak dosis $2240 \mathrm{mg} / \mathrm{kgBB}$ terjadi degenerasi vakuoler. Pada perlakuan dosis yang

Tabel 1 Jumlah mencit yang mati pada pengamatan 24 jam setelah pemberian oral ekstrak etanol daun jarak pagar (J. curcas)

\begin{tabular}{cllccc}
\hline Kelompok & \multicolumn{1}{c}{ Perlakuan } & $\mathrm{N}$ & Jumlah mencit mati & Respon $(\%)$ \\
\hline I & Larutan CMC-Na $0,5 \%$ & 5 & 0 & 0 \\
II & Sediaan uji dosis $1400 \mathrm{mg} / \mathrm{kgBB}$ & 5 & 0 & 0 \\
III & Sediaan uji dosis $2240 \mathrm{mg} / \mathrm{kgBB}$ & 5 & 0 & 0 \\
IV & Sediaan uji dosis $3584 \mathrm{mg} / \mathrm{kgBB}$ & 5 & 0 & 0 \\
V & Sediaan uji dosis $5734 \mathrm{mg} / \mathrm{kgBB}$ & 5 & 0 & 0 \\
\hline
\end{tabular}

Tabel 2 Hasil pemeriksaan gejala-gejala toksik dari mencit selama 24 jam setelah pemberian ekstrak etanol daun jarak pagar (J. curcas) secara oral dosis tunggal

\begin{tabular}{|c|c|c|c|c|c|c|c|}
\hline \multirow{2}{*}{ Kelompok } & \multirow{2}{*}{ Perlakuan } & \multirow{2}{*}{$\mathrm{N}$} & \multicolumn{5}{|c|}{ Gejala toksik } \\
\hline & & & Aktivitas motorik & Perubahan otot & Bentuk kulit & Defekasi & Perubahan BB \\
\hline I & Larutan CMC-Na 0,5\% & 5 & Tidak & Tidak & Tidak & Tidak & Tidak \\
\hline II & Sediaan uji dosis $1400 \mathrm{mg} / \mathrm{kgBB}$ & 5 & Tidak & Tidak & Tidak & Tidak & Tidak \\
\hline III & Sediaan uji dosis $2240 \mathrm{mg} / \mathrm{kgBB}$ & 5 & Tidak & Tidak & Tidak & Tidak & Tidak \\
\hline IV & Sediaan uji dosis $3584 \mathrm{mg} / \mathrm{kgBB}$ & 5 & Tidak & Tidak & Tidak & Tidak & Tidak \\
\hline $\mathrm{V}$ & Sediaan uji dosis $5734 \mathrm{mg} / \mathrm{kgBB}$ & 5 & lemah & Tidak & Tidak & Tidak & Tidak \\
\hline
\end{tabular}


Tabel 3 Hasil pemeriksaan histopatologis mencit setelah pemberian ekstrak etanol daun jarak pagar (J. curcas) secara oral dosis tunggal

\begin{tabular}{lccc}
\multicolumn{1}{c}{ Perlakuan } & Ginjal & Hati & Paru \\
\hline Larutan CMC-Na $0,5 \%$ & Normal & Normal & Normal \\
Sediaan uji dosis $1400 \mathrm{mg} / \mathrm{kgBB}$ & Peradangan & Peradangan, nekrosis & Peradangan(PI) \\
Sediaan uji dosis $2240 \mathrm{mg} / \mathrm{kgBB}$ & Normal & Peradangan, DV & Peradangan (PI) \\
Sediaan uji dosis $3584 \mathrm{mg} / \mathrm{kgBB}$ & Peradangan & Peradangan & Normal \\
Sediaan uji dosis $5734 \mathrm{mg} / \mathrm{kgBB}$ & Peradangan & Peradangan, nekrosis & Peradangan (PI) \\
\hline
\end{tabular}

Keterangan: DV: degenerasi vakuoler; PI: pneumonia intertitialis

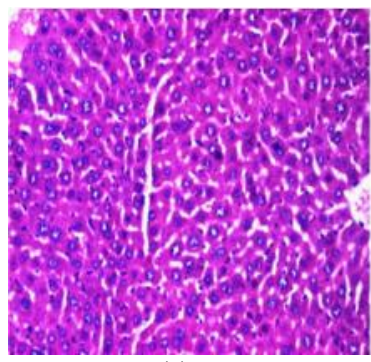

(a)

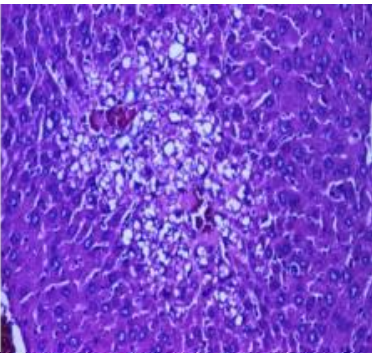

(b)

Gambar 1 Irisan melintang organ hati normal mencit jantan pengecatan hematoksilineosin (a) dan yang mengalami peradangan dan degenerasi vakuoler pada perlakuan ekstrak etanol daun jarak pagar (b) dengan perbesaran 100 kali

tertinggi (5734 mg/kgBB) dan dosis $1400 \mathrm{mg} / \mathrm{kgBB}$ terjadi nekrosis (Gambar 1).

Pada ginjal terjadi peradangan pada perlakuan dosis 2240, 3584, dan 5734 mg/kgBB (Gambar 2). Hal ini ditandai dengan adanya infiltrasi sel radang di sekitar pembuluh darah. Pada organ paru terjadi peradangan pada bronkiolus setelah pemejanan ekstrak dosis 1400, 2240, 3584, dan $5734 \mathrm{mg} / \mathrm{kgBB}$ (Gambar 3). Hal ini ditandai dengan adanya infiltrasi sel radang. Pneumonia interstitialis adalah reaksi inflamasi yang melibatkan dinding alveoli dengan eksudat yang relatif sedikit dan sel-sel lekosit poli-morfonuklear dalam jumlah yang relatif sedikit (Greaves et al. 2000). Dari hasil pemeriksaan histopatologi organ jantung tidak menunjukkan perbedaan yang signifikan antara kelompok kontrol dan perlakuan. Oleh sebab itu dapat disimpulkan bahwa pemberian sediaan uji tidak mempengaruhi organ jantung hewan uji kecuali pada perlakuan dosis tertinggi terdapat sedikit peradangan.

Penelitian sebelumnya telah dilakukan yaitu ekstrak etanol biji jarak pagar (J. curcas) pada dosis $200 \mathrm{mg} / \mathrm{kgBB}$ menimbulkan efek teratogen pada mencit karena mengandung forbol ester (Almahdy 2005; Prasad et al. 2012). Menurut Mishra et al. (2010) nilai LD $_{50}$ pada ekstrak etanol daun $J$. curcas sebagai antidiabetes pada mencit Swiss albino adalah $2500 \mathrm{mg} / \mathrm{kgBB}$ dengan dosis efektif sebesar $250 \mathrm{mg} / \mathrm{kgBB}$. Pemberian ekstrak etanol daun jarak pagar pada dosis 1400, 2240, 3584, dan $5734 \mathrm{mg} / \mathrm{kgBB}$ tidak menyebabkan kematian pada hewan uji akan tetapi bisa

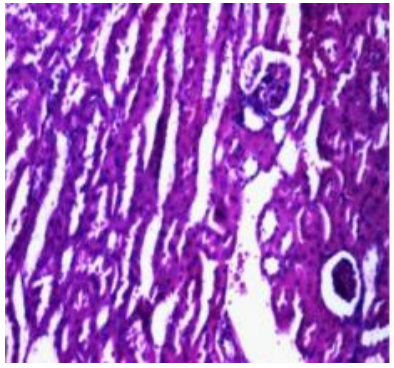

(a)

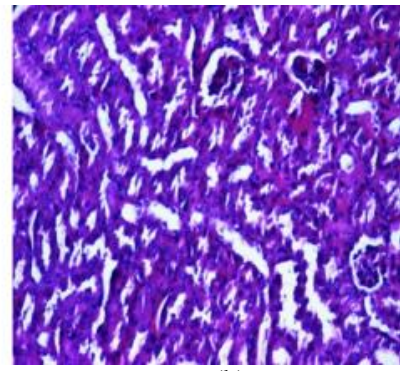

(b)
Gambar 2 Irisan melintang organ ginjal mencit jantan normal (a) yang mengalami peradangan (b) pengecatan hematoksilineosin dengan perbesaran 100x pada perlakuan ekstrak etanol daun jarak pagar

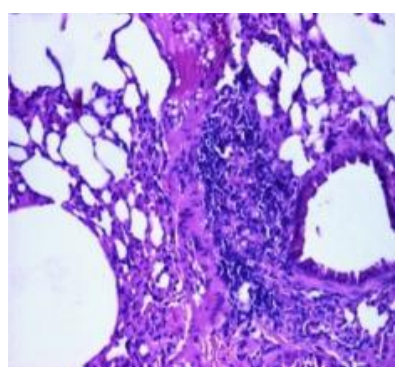

Gambar 3 Irisan melintang organ paru pada perlakuan ekstrak etanol daun jarak pada mencit jantan, yang mengalami peradangan, pengecatan hematoksilineosin dengan perbesaran 100x

menyebabkan ketoksikan pada organ hati, ginjal dan paru berupa peradangan dan degenerasi vakuoler dengan nilai $\mathrm{LD}_{50} 5734 \mathrm{mg} / \mathrm{kgBB}$. Berdasarkan penelitian ini, dapat disimpulkan bahwa ekstrak etanol daun jarak pagar praktis tidak toksik sehingga pada dosis 300 dan $500 \mathrm{mg} / \mathrm{kgBB}$ aman digunakan sebagai antiinflamasi dan bisa dikembangkan menjadi sediaan herbal yang efektif dan aman digunakan pada manusia.

\section{SIMPULAN}

Potensi ketoksikan akut $\left(\mathrm{LD}_{50}\right)$ dari ekstrak etanolik daun jarak pagar (J. curcas) yang diberikan secara oral dosis tunggal pada mencit jantan sebesar $5734 \mathrm{mg} / \mathrm{kgBB}$ dengan kategori praktis tidak toksik. Pemberian secara oral ekstrak etanolik daun jarak pagar pada mencit mulai dosis $1400 \mathrm{mg} / \mathrm{kgBB}$ sampai dengan $5734 \mathrm{mg} / \mathrm{kgBB}$ tidak menimbulkan gejala toksik secara klinis. Pemberian secara oral ekstrak etanolik daun jarak pagar (J. curcas) pada mencit 
mempengaruhi organ hati (peradangan, degenerasi vakuoler dan nekrosis), ginjal (peradangan) dan paru (peradangan).

\section{UCAPAN TERIMA KASIH}

Terima kasih kepada LPPM Universitas Jenderal Soedirman yang telah membantu memberikan fasilitas pada penelitian ini.

\section{DAFTAR PUSTAKA}

Akhila, J.S., Shyamjith, Deepa \& Alwar, M.C. 2007. Acute toxicity studies and determination of median lethal dose. Curr Sci 93(7): 917-920.

Almahdy, A. 2005. Uji efek teratogenitas ekstrak etanol Jatropa curcas L. pada mencit putih. Jurnal Farmasi Indonesia 3(2): 33-35.

Baroroh, H.N \& Warsinah. 2009. Antiinflammatory activity of ethanolic extract of leaves of jarak pagar (Jatropa curcas L.) and neutrophils profile in rats foot induced Carrageenan. Proceedings of International Conference On Medicinal Plants. Surabaya, 22-23 July 2009.

Departemen Kesehatan RI. 2000. Pedoman Pelaksanaan Uji Klinik Obat Tradisional, 1, 5, 14-15. DEPKES RI, Jakarta.

Greaves, M.B.P., Ch. B \& Path, F.R.C. 2000. Histopathology of Preclinical Toxicity Studies. Amsterdam: Elsevier.

Honggodipuro, F. 2007. Tanaman Obat Indonesia. http:// www.pdpersi.co.id. Diakses tanggal 8 Mei 2009.

Loomis, T. A. 1978. Toksikologi Dasar. diterjemahkan oleh Donatus,I.A. Ed. III. Semarang: IKIP Semarang Press.
Ma'at, S. 2004. Obat tradisional untuk pelayanan kesehatan formal. Prosiding Seminar Nasional. Surabaya, 5 September 2004.

Mishra, S.B., Vijayakumar, M., Ojha, S.K \& Verma,A. 2010. Antidiabetics effect of Jatropha curcas L. Leaves extract in normal and alloxan-induced diabetics rats. Int J Ph Sci 2(1): 481-487.

Oskueian, E.,Abdullah, N., Saad, W.Z., Omar,A.R.,Ahmad, S., Kuan, W.B., Zolkifli, N.A., Hendra, R \& Wan Ho,Y. 2011. Antioxidant, antiinflammatory and anticancer activities of methanolic extracts from Jatropha curcas Linn. J Med Plants Res 5(1): 49-57.

Prasad, D.M.R., Izam, A \& Khan, M.R. 2012. Jatropha curcas: plant of medical benefits. JMPR 6(14): 26912699.

Rathee, P., Chaudhary, H., Rathee, S., Rathee, D., Kumar, V \& Kohli, K. 2009. Mechanism of action of flavonoids as anti-inflammatory agents: a review. Inflamm. Allergy Drug Targets 8(3): 229-235.

Thomas, R., Sah, N \& Sharma, P. 2008. Therapeutic biology of jatropha curcas: A Mini Review. Curr Pharm Biotechnol 9(4): 315-324.

Uche, F.I \& Aprioku, J.S. 2008. The phytochemical constituents, analgesic and antiinflammatory effects of methanol extract of jatropha curcas leaves in mice and wister albino rats. J Appl Sci Environ Manage 12(4): 99-102.

Wahyono, D., Hakim, L., Nurlaila., Sulistio, M \& Ilyas, L. 2007. Uji toksisitas akut ekstrak etanolik terstandar dari kulit akar senggugu (Clerodendrum serratum L. Moon). Majalah Farmasi Indonesia 18(1): 1-7. 